\title{
Therapeutic Agents Rounding Up the Immunopathology of COVID-19
}

\author{
Hong Peng $\mathrm{Li}^{1,2, *}$ \\ Xuan $\mathrm{He}^{3, *}$ \\ Liu Zhang $\mathbb{1 D}^{1,2, *}$ \\ Chuan Xiang $\mathrm{Li}^{1,2,4}$ \\ Shi Qi Li $\mathbb{D}^{1,2}$ \\ Qing Yun $\mathrm{Li}^{1,2}$
}

'Department of Respiratory and Critical Care Medicine, Ruijin Hospital, Shanghai Jiao Tong University School of Medicine, Shanghai, 200025, People's Republic of China; ${ }^{2}$ Institute of Respiratory Medicine, Shanghai Jiao Tong University School of Medicine, Shanghai, 200025, People's Republic of China; ${ }^{3}$ Department of Pharmacy, Ruijin Hospital, Shanghai Jiao Tong University School of Medicine, Shanghai, 200025, People's Republic of China; ${ }^{4}$ Department of Respiratory Medicine, Wuhan No.3 Hospital, Wuhan, 430000, People's Republic of China

*These authors contributed equally to this work
Correspondence: Qing Yun Li

Department of Respiratory and Critical Care Medicine, Ruijin Hospital, Shanghai Jiao Tong University School of Medicine, No. 197 Rui Jin 2nd Road, Shanghai, 200025, People's Republic of China Tel +86-2I-64370045

Email liqingyun68@hotmail.com

\begin{abstract}
COVID-19 pandemic has caused more than 3 million deaths globally during the past year. The direct attack from SARS-CoV-2 and hyperactivated immune response contribute to the progress and deterioration of COVID-19. After the virus invades, the activation and release of cytokines/chemokines cause "cytokine storm", leading to acute respiratory distress syndrome (ARDS) and multiple organs dysfunction syndrome (MODS). Eliminating virus and blocking cytokines are important checkpoints of COVID-19 therapy, and several agents targeting immunopathology, including interferons, thymosin, glucocorticoids and immunoglobulin, have shown therapeutic effects in severe patients with COVID-19. Herein, we reviewed the practice evidences and concluded that several agents rounding up the immunopathology of COVID-19 may be the alternative approaches under the scenario of the lacking of effective antiviral drugs.
\end{abstract}

Keywords: COVID-19, immunotherapy, cytokines, corticosteroids, inflammation, monoclonal antibodies

\section{Importance}

The review provides a summary of the potential drugs related to immunopathology and the practice evidences. Strategies and theoretical bases for the immunological therapy of COVID-19 should be emphasized.

\section{Introduction}

The novel coronavirus disease 2019 (COVID-19), caused by acute respiratory syndrome coronavirus 2 (SARS-CoV-2), has been rapidly spreading across the globe despite drastic public health measures in 2020. Siddiqi and Mehra proposed 3 escalating phases of COVID-19 disease progression. ${ }^{1}$ During the initial stage, SARS-CoV-2 multiplies and establishes residence in the host, primarily focusing on the respiratory system. Complete blood count may be characterized by lymphopenia and neutrophilia. In the second stage of established pulmonary disease, viral multiplication and localized inflammation in the lung are the norm. A minority of COVID-19 patients will transition into the third and most severe stage of the illness, which manifests as an extrapulmonary systemic hyperinflammation syndrome. In this stage, systemic inflammation markers seem to be elevated. The hyper-inflammation and immune response deregulation contribute to the progress and deterioration of COVID-19 (Figure 1). ${ }^{2,3}$ The lymphopenia is related to delay and decrease of the elimination of virus, and increases the mortality. ${ }^{4-7}$ The cytokine storm results from a sudden increase of several pro-inflammatory cytokines including IL-6, and IL-1 $\beta$, as well as IL-2, IL-8, IL-17, G-CSF, GM-CSF, IP10, MCP1, IFN- $\gamma$, TNF- $\alpha$ and 
MIP1 $\alpha$, etc. $^{8}$ IL-6 is a crucial protagonist for the development of cytokine storm with increased level and lasted for longer duration in severe patients. ${ }^{6,9,10}$ IL-6 further promotes a waterfall-like release of other pro-inflammatory cytokines. $^{4,8,11}$ Besides, monocytes and neutrophils also involve in the cytokine releasing in the severe patients. ${ }^{12-14}$ Eventually, the cytokine storm leads to multiple organs dysfunction syndrome (MODS) and the death (Figure 1). ${ }^{15}$ Thus, halting the cytokine storm will be an alternative strategy to improve the outcome for COVID-19. Therefore, we summarized current opinion on the use of several drugs targeting immunopathology in COVID-19 by reviewing the practice evidences available (Table 1), including interferons, thymosin, glucocorticoids (GCs), tocilizumab, and anakinra, etc. ${ }^{16}$ In addition, commercial intravenous $\gamma$-Immunoglobulin (IVIG), convalescent plasma, and monoclonal antibodies are also investigated for their function in the elimination of virus. ${ }^{17,18}$

\section{Methods of Selecting Studies for This Review}

We conducted a comprehensive literature search in PubMed and EMBASE for English-language articles with available full text that had been published through March 5, 2021. The search terms were combinations of "COVID-19" OR "Coronavirus disease 2019" OR "SARS-CoV-2" AND "Thymosin", "COVID-19”, OR "SARS-CoV-2" AND "IFN" or "interferon", "COVID-19” OR "Coronavirus disease 2019” OR "SARS-CoV-2" AND "Glucocorticoids" or "Methylprednisolone" or "Dexamethasone" or "steroid", “COVID-19” OR "Coronavirus disease 2019” OR "SARSCoV-2" AND "Tocilizumab" or "TCZ" or "IL-6 receptor Antagonist" or "IL-6 receptor blockade", "COVID-19” OR "Coronavirus disease 2019" OR "SARS-CoV-2" AND "Anakinra" or "IL-1 receptor blockade" or "IL-1 receptor Antagonist" or "Canakinumab", "COVID-19" OR
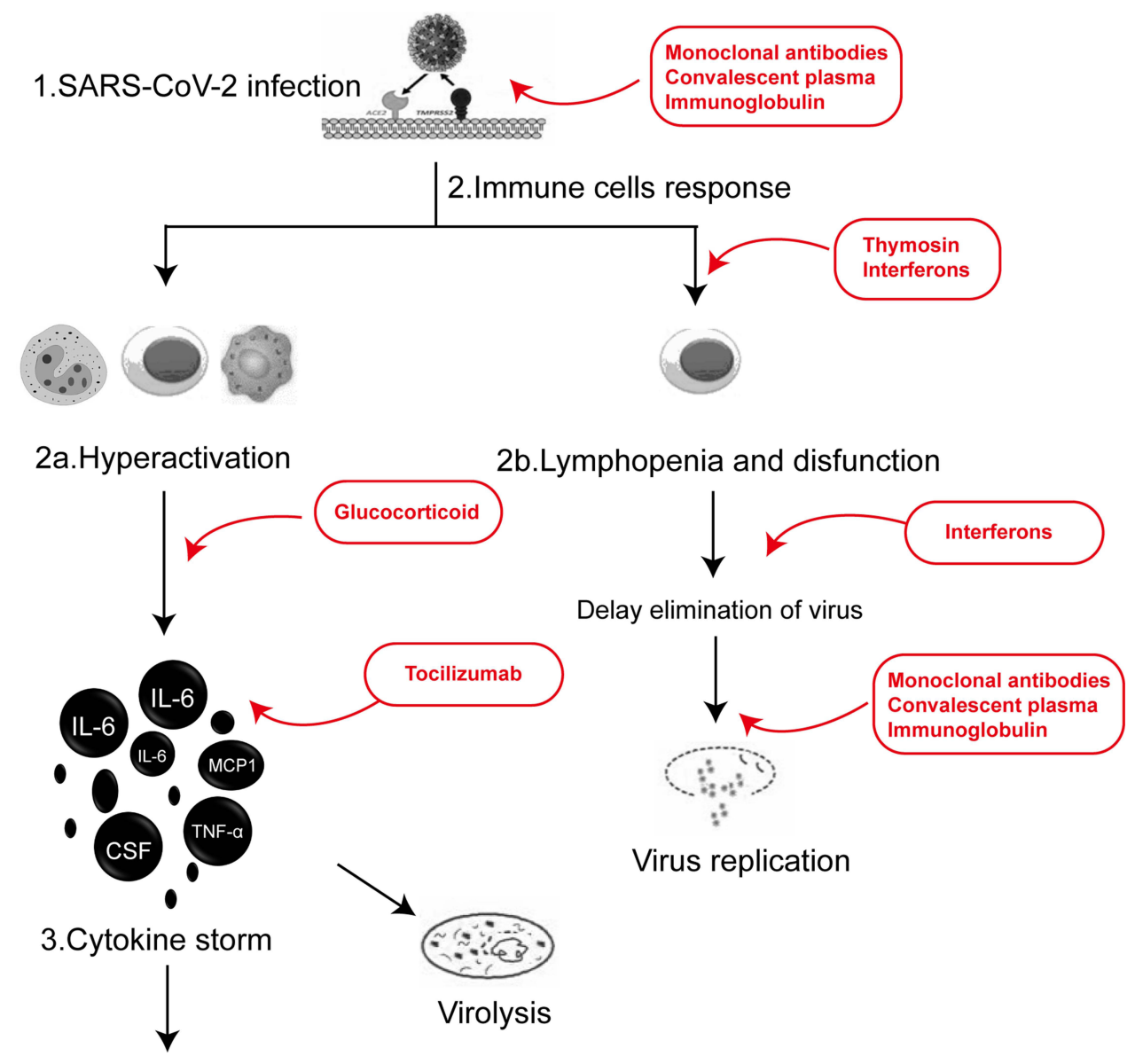

4. MODS

Figure I Underlining mechanisms of pathogenesis and potential treatment agents in different steps (numbered) rounding up the immunopathology of COVID-19. I. Elimination of virus: monoclonal antibodies, inhaling IFN, convalescent plasma and IVIG. 2. Halting hyperreaction and T cell destruction: thymosin (effect of immune regulation and immunosuppression), IVIG and IFN. 3. GC and IL antibodies: inhibiting the cytokines storms.

Abbreviations: IL-6, interleukin-6; IL-I $\beta$, interleukin-I $\beta$; TNF- $\alpha$, tumor necrosis factor- $\alpha$; MCPI, monocyte chemotactic protein I. 
Table I Clinical Evidence for the Use of Agents Rounding Up the Immunopathology of COVID-I9

\begin{tabular}{|c|c|c|c|c|c|c|}
\hline Agents & $\begin{array}{l}\text { Author, } \\
\text { Year, } \\
\text { Reference }\end{array}$ & Country & $\begin{array}{l}\text { Study Design } \\
\text { (Follow-Up), } \\
\text { Number }\end{array}$ & $\begin{array}{l}\text { Treatment } \\
\text { Regimens }\end{array}$ & Primary Endpoint & Outcomes \\
\hline IFN- $\alpha-2 b$ & $\begin{array}{l}\text { Zhou } Q \text { et al, } \\
2020,{ }^{30}\end{array}$ & China & $\begin{array}{l}\text { Uncontrolled, } \\
\text { exploratory study } \\
\text { (Jan. } 16 \text { to Feb. } 20 \text {, } \\
\text { 2020), n=77 }\end{array}$ & $5 \mathrm{mU}$ b.i.d. & $\begin{array}{l}\text { Mean days of detectable } \\
\text { virus in the upper } \\
\text { respiratory tract }\end{array}$ & $\begin{array}{l}\text { IFN- } \alpha-2 b: 21.2 \text { Id } \\
\text { ARB+IFN- } \alpha-2 b: 20.3 d \\
\text { ARB: } 27.9 d\end{array}$ \\
\hline $\begin{array}{l}\text { IFN- } \beta-\mathrm{Ib+} \\
\text { Ribavirin }\end{array}$ & $\begin{array}{l}\text { Hung IF et al, } \\
2020,{ }^{24}\end{array}$ & China & $\begin{array}{l}\text { RCT, prospective } \\
\text { (Feb. } 10 \text { to Mar. } 20, \\
2020), n=127\end{array}$ & $\begin{array}{l}8 \text { million IU (three } \\
\text { doses on alternate } \\
\text { days over a period of } \\
\text { I4 days) } \\
\text { Ribavirin: } 400 \mathrm{mg} \\
\mathrm{q} / 2 \mathrm{~h}\end{array}$ & $\begin{array}{l}\text { The time to providing } \\
\text { a nasopharyngeal swab } \\
\text { negative for SARS-CoV-2 } \\
\text { RT-PCR }\end{array}$ & $\begin{array}{l}\text { IFN- } \beta-\text { Ib+Ribavirin: } 7 d \\
\text { Control: I2d }\end{array}$ \\
\hline IFN- $\beta-\mathrm{Ia}$ & $\begin{array}{l}\text { WHO } \\
\text { Solidarity Trial } \\
\text { Consortium, } \\
2021,{ }^{25}\end{array}$ & $\begin{array}{l}30 \\
\text { countries }\end{array}$ & $\begin{array}{l}\text { RCT (Mar. } 22 \text { to } \\
\text { Oct. } 4,2020) \\
n=4 \mid 27 \text { (65I: IFN } \beta- \\
\text { la plus lopinavir) }\end{array}$ & $\begin{array}{l}44 \mu \mathrm{g} \text { (three doses } \\
\text { over a period of } 6 \\
\text { days, mainly } \\
\text { subcutaneous) }\end{array}$ & In-hospital mortality & $\begin{array}{l}\text { IFN } \beta \text {-I a: } 243 \text { of } 2050 \text { vs } \\
\text { Control: } 216 \text { of } 2050 \\
\text { (Rate ratio, I.16; } 95 \% \mathrm{Cl}, 0.96 \text { to } \\
\text { I.39; P=0.1 I) }\end{array}$ \\
\hline Peg-IFN $\lambda-I$ & $\begin{array}{l}\text { Feld JJ et al, } \\
202 I^{26}\end{array}$ & Canada & $\begin{array}{l}\text { RCT (May. } 18 \text { to } \\
\text { Sept. } 4,2020 \text { ), }\end{array}$ & $\begin{array}{l}\text { I } 80 \mu g \text { (a single } \\
\text { subcutaneous } \\
\text { injection) }\end{array}$ & $\begin{array}{l}\text { SARS-CoV-2 RNA } \\
\text { negative proportion } \\
\text { on day } 7 \text { after the } \\
\text { injection }\end{array}$ & $\begin{array}{l}\text { Peg-IFN } \lambda \text {-I: } 24(80 \%) \text { vs } \\
\text { Control: } 19(63 \%)(p=0.15)\end{array}$ \\
\hline Thymosin & $\begin{array}{l}\text { Wu M et al, } \\
2020,{ }^{35}\end{array}$ & China & $\begin{array}{l}\text { Retrospective } \\
\text { cohort study } \\
\text { (Dec. } 2019 \text { to Mar., } \\
\text { 2020), } n=334\end{array}$ & $\begin{array}{l}1.6 \mathrm{mg} q \mathrm{qd}, \text { or } \mathrm{q} / 2 \\
\mathrm{~h} \text { for }>5 \text { days }\end{array}$ & $\begin{array}{l}\text { 28-day and } 60 \text {-day } \\
\text { mortality }\end{array}$ & $\begin{array}{l}\text { 28-day mortality } \\
\text { Thymosin: } 8 \text { of } 102(7.8 \%) \text { vs } \\
\text { Control: } 34 \text { of } 232(14.7 \%) \\
(p=0.016) \\
60 \text {-day mortality } \\
\text { Thymosin: } 20 \text { of } 102(19.6 \%) \text { vs } \\
\text { Control: } 35 \text { of } 232(15.1 \%) \\
(p=1.000)\end{array}$ \\
\hline Thymosin & $\begin{array}{l}\text { Li X et al, } \\
2020,^{36}\end{array}$ & China & $\begin{array}{l}\text { Retrospective study } \\
\text { (Jan.30 to Apr.2, } \\
2020), n=127\end{array}$ & $\begin{array}{l}\text { I.6 } \mathrm{mg} T \alpha \mid \text { (a } \\
\text { subcutaneous } \\
\text { injection) }\end{array}$ & $\begin{array}{l}\text { Gender differences in } \\
\text { CRP, PCT and IL-6 levels }\end{array}$ & $\begin{array}{l}\text { Female: the levels of CRP and IL- } \\
6 \text { decreased } \\
\text { Males: the decrease of CRP was } \\
\text { not significant, and the level of IL- } \\
6 \text { was significantly higher than } \\
\text { that in females. }\end{array}$ \\
\hline Thymosin & $\begin{array}{l}\text { Sun } Q \text { et al, } \\
2020,{ }^{38}\end{array}$ & China & $\begin{array}{l}\text { Retrospective study } \\
\text { (Jan.I to Feb.29, } \\
\text { 2020), } n=77 \text { I }\end{array}$ & Not available & 28-day mortality & $\begin{array}{l}\text { Thymosin: } 8 \text { of } 102(51 \%) \text { vs } \\
\text { Control: } 34 \text { of } 232(52.9 \%) \\
(p>0.05)\end{array}$ \\
\hline Methylprednisolone & $\begin{array}{l}\text { Xiang } Z \text { et al, } \\
2020{ }^{43}\end{array}$ & China & $\begin{array}{l}\text { Retrospective study, } \\
\mathrm{n}=9\end{array}$ & $\begin{array}{l}\text { Body weight } \leq 80 \mathrm{~kg} \\
\text { first } 3-4 \text { days: } 40 \mathrm{mg} / \\
\text { d } \\
\text { next } 3 \text { days: } 20 \mathrm{mg} / \mathrm{d} \\
\text { Body weight } \geq 80 \mathrm{~kg} \\
\text { first } 3-4 \text { days: } 80 \mathrm{mg} / \\
\text { d } \\
\text { next } 3 \text { days: } 40 \mathrm{mg} / \mathrm{d}\end{array}$ & $\begin{array}{l}\text { Clinical parameters: } \\
\text { lymphocyte ratio; CRP; } \\
\text { IL-6 cytokine levels; } \\
\text { chest CT images }\end{array}$ & Significant improvement: 7 of 9 \\
\hline Dexamethasone & $\begin{array}{l}\text { RECOVERY } \\
\text { Collaborative } \\
\text { Group et al, } \\
2020,44\end{array}$ & $\begin{array}{l}\text { United } \\
\text { Kingdom }\end{array}$ & $\begin{array}{l}\text { RCT (Mar. } 19 \text { to } \\
\text { Jun. } 8,2020 \text { ), } \\
n=6425\end{array}$ & $\begin{array}{l}6 \mathrm{mg} \text { (oral or } \\
\text { intravenous once } \\
\text { daily) }\end{array}$ & 28-day mortality & $\begin{array}{l}\text { Dexamethasone: } 482 \text { of } 2104 \\
\text { (22.9\%) vs } \\
\text { Control: } 1110 \text { of } 4321(25.7 \%) \\
(p<0.001)\end{array}$ \\
\hline
\end{tabular}

(Continued) 
Table I (Continued).

\begin{tabular}{|c|c|c|c|c|c|c|}
\hline Agents & $\begin{array}{l}\text { Author, } \\
\text { Year, } \\
\text { Reference }\end{array}$ & Country & $\begin{array}{l}\text { Study Design } \\
\text { (Follow-Up), } \\
\text { Number }\end{array}$ & $\begin{array}{l}\text { Treatment } \\
\text { Regimens }\end{array}$ & Primary Endpoint & Outcomes \\
\hline $\begin{array}{l}\text { Methylprednisolone } \\
\text { Dexamethasone }\end{array}$ & $\begin{array}{l}\text { Ko JJ et al, } \\
2021,{ }^{45}\end{array}$ & USA & $\begin{array}{l}\text { Cohort study } \\
\text { (Mar. I to Jul. 3I), } \\
n=262\end{array}$ & $\begin{array}{l}\text { Methylprednisolone } \\
\mathrm{Img} / \mathrm{kg} / \text { day for } \geq \\
\text { 3days } \\
\text { Dexamethasone } \\
6 \mathrm{mg} / \text { day for } \geq 7 \text { days }\end{array}$ & Mortality within 50 days & $\begin{array}{l}\text { Methylprednisolone: } 16.4 \% \\
\text { Dexamethasone: } 26.5 \% \text { vs } \\
\text { Control: } 41.3 \%(p<0.001)\end{array}$ \\
\hline Tocilizumab & $\begin{array}{l}\text { Luo } P \text { et al, } \\
2020,,^{52}\end{array}$ & China & $\begin{array}{l}\text { Retrospective study } \\
\text { (Jan. } 27 \text { to Mar. } 5 \text {, } \\
\text { 2020), } n=15\end{array}$ & $\begin{array}{l}80 \text { to } 600 \mathrm{mg} \text { per } \\
\text { time }\end{array}$ & $\begin{array}{l}\text { CRP } \\
\text { IL-6 level }\end{array}$ & $\begin{array}{l}\text { I26.9 (10.7-257.9) to II.2 }(0.02- \\
\text { II } 3.7) \mathrm{mg} / \mathrm{L}(\mathrm{p}<0.0 \mathrm{I}) \\
\text { In } 10(66.7 \%) \text { patients decreased }\end{array}$ \\
\hline Tocilizumab & $\begin{array}{l}\text { Toniati P et al, } \\
2020^{53}\end{array}$ & Italy & $\begin{array}{l}\text { Prospective study } \\
\text { (Mar. } 9 \text { to Mar. 20), } \\
\mathrm{n}=100\end{array}$ & $\begin{array}{l}8 \mathrm{mg} / \mathrm{kg} \text { (max } \\
800 \mathrm{mg} \text { ) by two } \\
\text { consecutive } \\
\text { intravenous infusions } \\
12 \mathrm{~h} \text { apart. }\end{array}$ & $\begin{array}{l}\text { Lymphocyte count; levels } \\
\text { of CRP, fibrinogen, ferritin } \\
\text { and IL-6; } \\
\text { respiratory condition }\end{array}$ & $\begin{array}{l}\text { Increased } \\
\text { Decreased } \\
\text { improved or stabilized in } 77 \\
(77 \%) \text { patients }\end{array}$ \\
\hline Tocilizumab & $\begin{array}{l}\text { REMAP-CAP } \\
\text { Investigators } \\
\text { et al, } 2021^{54}\end{array}$ & NA & $\begin{array}{l}\text { RCT (Mar.9 to } \\
\text { Jun. 17), } n=803\end{array}$ & $8 \mathrm{mg} / \mathrm{kg}$ & $\begin{array}{l}\text { Respiratory and } \\
\text { cardiovascular organ } \\
\text { support-free days }\end{array}$ & $\begin{array}{l}\text { Tocilizumab: } 10(-1 \text { to } 16) \text { vs } \\
\text { Control: } 0(-1 \text { to } 15)\end{array}$ \\
\hline Tocilizumab & $\begin{array}{l}\text { Perrone } \\
\text { F et al, } \\
2020,^{55}\end{array}$ & Italy & $\begin{array}{l}\text { Single-arm } \\
\text { hypothesis -driven } \\
\text { phase } 2 \text { study } \\
\text { (Mar. } 19 \text { to } 20 \text {, } \\
\text { 2020), } n=301 \\
\text { Validation cohort } \\
\text { (Mar. } 20 \text { to } 24 \text {, } \\
\text { 2020), } n=920\end{array}$ & $\begin{array}{l}8 \mathrm{mg} / \mathrm{kg} \text { to } \\
\text { a maximum of } \\
800 \mathrm{mg} \text { per dose }\end{array}$ & $\begin{array}{l}\text { Lethality rates at } 14 \text { and } \\
30 \text { days (expected } \\
\text { lethality rates at } 14 \text { and } \\
30 \text { days: } 2 \% \text { and } 35 \% \text { ) }\end{array}$ & $\begin{array}{l}\text { Phase 2: } \\
\text { I4-day: } 55 \text { of } 299(18.4 \%) \\
\text { 30-day: } 67 \text { of } 299(22.4 \%) \\
\text { Validation } \\
\text { |4-day: } 101 \text { of } 884(11.4 \%) \\
\text { 30-day: } 158 \text { of } 858(18.4 \%)\end{array}$ \\
\hline Tocilizumab & $\begin{array}{l}\text { Stone JH et al, } \\
2020^{57}\end{array}$ & USA & $\begin{array}{l}\text { RCT (Apr. } 20 \text { to } \\
\text { Jun. 15), } n=243\end{array}$ & $\begin{array}{l}8 \mathrm{mg} / \mathrm{kg} \text { to } \\
\text { a maximum of } \\
800 \mathrm{mg}\end{array}$ & $\begin{array}{l}\text { Intubation or 28-day } \\
\text { mortality }\end{array}$ & $\begin{array}{l}\text { Tocilizumab: } 17 \text { of } 161 \text { (10.6\%) vs } \\
\text { Placebo: } 10 \text { of } 81 \text { (12.5\%) }\end{array}$ \\
\hline Tocilizumab & $\begin{array}{l}\text { Veiga VC et al, } \\
2021,{ }^{58}\end{array}$ & Brazil & $\begin{array}{l}\text { RCT (May. } 8 \text { to } \\
\text { Jul. } 17,2020 \text { ), } n=129\end{array}$ & $\begin{array}{l}8 \mathrm{mg} / \mathrm{kg} \text { (single } \\
\text { intravenous infusion) }\end{array}$ & $\begin{array}{l}\text { Death or mechanical } \\
\text { ventilation at } 15 \text { days }\end{array}$ & $\begin{array}{l}\text { Tocilizumab: } 18 \text { of } 65(28 \%) \text { vs } \\
\text { Control: } 13 \text { of } 64(20 \%)\end{array}$ \\
\hline Anakinra & $\begin{array}{l}\text { CORIMUNO- } \\
19 \\
\text { Collaborative } \\
\text { group et al, } \\
2021,{ }^{60}\end{array}$ & France & $\begin{array}{l}\text { Bayesian RCT } \\
\text { (Apr. } 8 \text { to Apr. 26, } \\
\text { 2020), } n=116\end{array}$ & $\begin{array}{l}200 \mathrm{mg} \text { twice a day } \\
\text { on days I-3, } \\
100 \mathrm{mg} \text { twice on day } \\
4, \\
100 \mathrm{mg} \text { once on day } \\
5 \\
\text { IL-6 inhibitors } \\
\text { (Tocilizumab/ } \\
\text { Sarilumab): a single } \\
\text { dose of } 400 \mathrm{mg}\end{array}$ & $\begin{array}{l}\text { A score of }>5 \text { on the } \\
\text { WHO-CPS at day } 4 \\
\text { Need ventilation or died } \\
\text { at day } 14\end{array}$ & $\begin{array}{l}\text { A score of }>5 \text { on the WHO- } \\
\text { CPS at day } 4 \\
\text { Anakinra: } 2 \text { I of } 59(36 \%) \\
\text { Control: } 2 \text { I of } 55(38 \%) \\
\text { Need ventilation or died at day } \\
\text { I4 } \\
\text { Anakinra: } 28 \text { of } 59(47 \%) \\
\text { Control: } 28 \text { of } 55(51 \%)\end{array}$ \\
\hline $\begin{array}{l}\text { IL receptor } \\
\text { blockade }\end{array}$ & $\begin{array}{l}\text { Cavalli G et al, } \\
2021,{ }^{61}\end{array}$ & Italy & $\begin{array}{l}\text { Cohort study } \\
\text { (Feb. } 25 \text { to May. 20, } \\
\text { 2020), n=392 }\end{array}$ & $\begin{array}{l}\text { Anakinra: } 5 \mathrm{mg} / \mathrm{kg} \\
\text { twice daily } \\
\text { Tocilizumab/ } \\
\text { Sarilumab: a single } \\
\text { dose of } 400 \mathrm{mg}\end{array}$ & Survival & $\begin{array}{l}\text { Anakinra vs Control } \\
74 \text { of } 100(86 \%) \text { vs. } 61 \text { of } 75 \\
(68 \%)(p=0.047) \\
\text { IL-6 inhibitors vs Control } \\
69 \text { of } 97(82 \%) \text { vs.6I of } 75(68 \%) \\
(p=0.79)\end{array}$ \\
\hline
\end{tabular}

(Continued) 
Table I (Continued).

\begin{tabular}{|c|c|c|c|c|c|c|}
\hline Agents & $\begin{array}{l}\text { Author, } \\
\text { Year, } \\
\text { Reference }\end{array}$ & Country & $\begin{array}{l}\text { Study Design } \\
\text { (Follow-Up), } \\
\text { Number }\end{array}$ & $\begin{array}{l}\text { Treatment } \\
\text { Regimens }\end{array}$ & Primary Endpoint & Outcomes \\
\hline Anakinra & $\begin{array}{l}\text { Cauchois } \\
\text { R et al, } \\
2020,{ }^{62}\end{array}$ & France & $\begin{array}{l}\text { Retrospective study } \\
(20 d), n=22\end{array}$ & $\begin{array}{l}\text { A single dose of } \\
300 \mathrm{mg} / \mathrm{d} \text { for } 5 \mathrm{~d} ; \\
200 \mathrm{mg} / \mathrm{d} \text { for } 2 \mathrm{~d} \\
100 \mathrm{mg} / \mathrm{d} \text { for } \mathrm{Id}\end{array}$ & $\begin{array}{l}\text { NEWS score (severity) at } \\
\text { D5 } \\
\text { Days with } \mathrm{O} 2<3 \mathrm{~L} / \mathrm{min} \\
\text { ICU free days } \\
\text { Invasive ventilation free } \\
\text { days } \\
\text { Death, } \mathrm{n}(\%)\end{array}$ & $\begin{array}{l}\text { Anakinra vs Control } \\
4.5 \text { vs. } 8(p<0.01) \\
15.5 \text { vs. } 8(p<0.05) \\
17.5 \text { vs. } 14 \\
20 \text { vs. } 17 \\
0(0 \%) \text { vs. } 1(10 \%)\end{array}$ \\
\hline Anakinra & $\begin{array}{l}\text { Cavalli G et al, } \\
2020,{ }^{63}\end{array}$ & Italy & $\begin{array}{l}\text { Retrospective } \\
\text { cohort study }(2 \mid d) \text {, } \\
n=52\end{array}$ & $\begin{array}{l}\text { High-dose: } 5 \mathrm{mg} / \mathrm{kg} \\
\text { twice daily }\end{array}$ & $\begin{array}{l}\text { Survival } \\
\text { MV-free survival } \\
\text { Respiratory function } \\
\text { improvement }\end{array}$ & $\begin{array}{l}\text { Anakinra }(n=29) \text { vs Control } \\
(n=16) \\
90 \% \text { vs. } 56 \%(p=0.009) \\
72 \% \text { vs. } 50 \%(p=0.15) \\
21 \text { ( } 72 \%) \text { vs. } 8(50 \%)\end{array}$ \\
\hline Anakinra & $\begin{array}{l}\text { Huet T et al, } \\
2020,{ }^{64}\end{array}$ & France & $\begin{array}{l}\text { Cohort study } \\
\text { (Mar. } 24 \text { to Apr. } 6 \\
\text { 2020), } n=96\end{array}$ & $\begin{array}{l}100 \mathrm{mg} \text { twice a day } \\
\text { for } 3 \mathrm{~d} \\
100 \mathrm{mg} \text { daily for } 7 \\
\text { days }\end{array}$ & $\begin{array}{l}\text { Admission to the ICU for } \\
\text { IMV or death }\end{array}$ & $\begin{array}{l}\text { Anakinra group: } 13 \text { of } 52(25 \%) \\
\text { Historical group: } 32 \text { of } 44(73 \%)\end{array}$ \\
\hline Canakinumab & $\begin{array}{l}\text { Landi } L \text { et al, } \\
2020,65\end{array}$ & Italy & $\begin{array}{l}\text { Prospective cohort } \\
\text { study (30d), } n=88\end{array}$ & $300 \mathrm{mg} \mathrm{sc}$ & $\begin{array}{l}\text { Median } \mathrm{PaO} 2 / \mathrm{FiO} 2 \\
\text { Median duration of } \\
\text { hospitalization } \\
\text { Death at } 7 \text { days } \\
\text { Overall survival at I } \\
\text { month }\end{array}$ & $\begin{array}{l}\text { From } 160 \text { at baseline to } 237 \\
6 \mathrm{~d} \\
12 \text { of } 88(13.6 \%) \\
79.5 \%\end{array}$ \\
\hline Canakinumab & $\begin{array}{l}\text { Generali } \\
\text { D et al, } \\
2020,{ }^{66}\end{array}$ & Italy & $\begin{array}{l}\text { Prospective case- } \\
\text { control study (0I-25 } \\
\text { Apr. 2020), } n=48\end{array}$ & $\begin{array}{l}150 \mathrm{mg} \text { on day I } \\
\text { and day } 7\end{array}$ & Survival rate at 60 days & $\begin{array}{l}\text { Canakinumab: } 90.0 \% \\
\text { Control: } 73.3 \%\end{array}$ \\
\hline IVIG & $\begin{array}{l}\text { Xie Y et al, } \\
2020,{ }^{68}\end{array}$ & China & $\begin{array}{l}\text { Retrospective study } \\
\text { (Jan. to Feb. 2020), } \\
n=58\end{array}$ & $20 \mathrm{~g} /$ day & 28-day mortality & $\begin{array}{l}\leq 48 \mathrm{~h} \text { group } \\
7 \text { of } 30(23.3 \%) \\
>48 \mathrm{~h} \text { group } \\
16 \text { of } 28(57.1 \%)(p=0.009)\end{array}$ \\
\hline IVIG Infliximab & $\begin{array}{l}\text { Farrokhpour } \\
\text { M et al, } \\
2021,{ }^{69}\end{array}$ & Iran & $\begin{array}{l}\text { Cohort study (Mar, } \\
\text { 2020), n= } 104\end{array}$ & $\begin{array}{l}\text { IVIG: } 400 \mathrm{mg} / \mathrm{kg} / \mathrm{d} \text { for } \\
3 \text { to } 5 \text { days } \\
\text { Infliximab: a single } \\
\text { dose of } 5 \mathrm{mg} / \mathrm{kg}\end{array}$ & Death & $\begin{array}{l}\text { IVIG: } 6 \text { of } 23(26.1 \%) \\
\text { Infliximab: } 10 \text { of } 27(37 \%) \\
\text { Combination Therapy: } 5 \text { of II } \\
(45.5 \%) \text { vs } \\
\text { Control: } 27 \text { of } 43(62.8 \%) \text { (all } P< \\
0.05 \text { ) }\end{array}$ \\
\hline IVIG & $\begin{array}{l}\text { R S R et al, } \\
2021,{ }^{70}\end{array}$ & India & $\begin{array}{l}\text { Phase-II RCT (Jul. to } \\
\text { Sept., 2020), } n=100\end{array}$ & $0.4 \mathrm{~g} / \mathrm{kg} / \mathrm{d}$ for 5 days & $\begin{array}{l}\text { Number of days of } \\
\text { hospitalization }\end{array}$ & $\begin{array}{l}\text { IVIG: } 7.72 \text { vs } \\
\text { Control: } 17.5(p<0.01)\end{array}$ \\
\hline IVIG & $\begin{array}{l}\text { Huang } C \text { et al, } \\
2021,71\end{array}$ & China & $\begin{array}{l}\text { Retrospective } \\
\text { Cohort Study } \\
\text { (Jan.20 to Jun. 10, } \\
2020), n=639\end{array}$ & $\begin{array}{l}10 \mathrm{~g} / \text { day for } 3 / 5 \text { days, } \\
20 \mathrm{~g} / \text { day for } 3 / 5 \text { days, }\end{array}$ & $\begin{array}{l}\text { Severity rate } \\
\text { Mortality rate }\end{array}$ & $\begin{array}{l}\text { IVIG: } 3 \text { of } 45(6.6 \%) \text { vs } \\
\text { Control: } 3 \text { of } 90(3.3 \%)(p>0.05) \\
\text { IVIG: I of } 45(2.2 \%) \text { vs } \\
\text { Control: } 0 \text { of } 90(p>0.05)\end{array}$ \\
\hline $\begin{array}{l}\text { Convalescent } \\
\text { plasma }\end{array}$ & $\begin{array}{l}\text { Duan } \mathrm{K} \text { et al, } \\
2020,^{74}\end{array}$ & China & $\begin{array}{l}\text { Retrospective study } \\
\text { (Jan. } 23 \text { to Feb. } 19 \text {, } \\
\text { 2020), } n=10\end{array}$ & & $\begin{array}{l}\text { Improvement of clinical } \\
\text { symptoms: } \\
\text { fever, cough, shortness of } \\
\text { breath, and chest pain; } \\
\text { Reduction of pulmonary } \\
\text { lesions on chest CT } \\
\text { examinations }\end{array}$ & $\begin{array}{l}10 \text { patients } \\
\text { different degrees of absorption in } \\
10 \text { patients }\end{array}$ \\
\hline
\end{tabular}

Abbreviations: RCT, randomized controlled trial; IL-6, interleukin-6; ICU, intensive care unit; CRP, C-reactive protein; IVIG, intravenous $\gamma$-immunoglobulin. 
"Coronavirus disease 2019" OR "SARS-CoV-2" AND "Intravenous $\gamma$-Immunoglobulin" or "IVIG", as well as combinations of "COVID-19" OR "Coronavirus disease 2019" OR "SARS-CoV-2" AND “convalescent plasma”. Metaanalyses, case report and review articles were not included but were screened for additional studies that were not found in the initial electronic search. Titles and abstracts were evaluated in order to determine the applicability of each individual study. Finally, 28 papers were retained for this review.

\section{Target Therapeutic Agents Rounding Up the Immunopathology Interferons}

Type I interferons (IFNs), including IFN- $\alpha$ and IFN- $\beta$, are highly active and multifunctional secreted glycoproteins with antiviral, antitumor, and immunomodulatory functions, ${ }^{19}$ which regulate the expression of a series of genes, through binding of IFNs to specific receptors located on the cell membrane. IFNs exert antiviral effect by inhibiting virus replication and regulating immune function. ${ }^{20} \mathrm{McNab}$ has found the deficiency of type-I IFNs might be an indicator of severe COVID-19, ${ }^{21}$ for no IFN- $\beta$ and low IFN- $\alpha$ production and activity were found in the severe and critical patients, which were associated with a persistent blood viral load and an exacerbated inflammatory response. IFNs help to eliminate the SARS-CoV-2 by improving the phagocytic function of macrophages and the activity of $\mathrm{T}$ lymphocytes, or by inducing the synthesis of antiviral protein (AVP) of host cells. Thus, type I IFNs have emerged as potential drugs against SARS-CoV-2. ${ }^{22}$ Zhou et al found that IFN- $\alpha 2 b$, with or without oral umifenovir hydrochloride, reduced the duration of detectable virus in the upper airway significantly in 53 moderate COVID-19 patients than those who used umifenovir hydrochloride only (21.1 days vs 27.9 days). ${ }^{23}$ Over the time period from day 12 (the onset of symptoms) to day 42 , patients treated with IFN- $\alpha 2 b$ had lower IL-6 levels $(33.5 \mathrm{pg} / \mathrm{mL})$ and higher CRP levels $(25.7 \mathrm{mg} / \mathrm{L})$ than those without IFN- $\alpha 2 \mathrm{~b}$ treatment. A multicenter study reported that the antivirus therapy combined with IFN- $\beta-1 \mathrm{~b}$ ( 8 million IU on alternate days, $\mathrm{iH}$ ) had a significantly shorter median time from start of treatment to negative nasopharyngeal swab virus test [7 days (IQR 5-11)] than the control group [12 days (8-15); HR 4.37 (95\% CI 1.86-10.24), $\mathrm{p}=0 \cdot 0010]$, and days of hospital stay in 86 patients with mild to moderate COVID-19 [9.0 days (7.013.0) vs 14.5 days (9.3-16.0); HR 2.72 (1.2-6.13), $\mathrm{p}=$ $0 \cdot 016]{ }^{24}$ As for the mortality, unfortunately, an interim WHO solidarity trial results did not show that IFN- $\beta-1$ definitely reduced initiation of ventilation or hospitalization duration, and the mortality either (Death occurred in 243/2050 with interferon vs $216 / 2050$ in control, $\mathrm{P}=0.11) .{ }^{25}$

IFN III (IFN- $\lambda$ ) imposes the antivirus effects via binding and inducing signaling through the heterodimeric IFN- $\lambda$ receptor (IFNLR). A recent Phase 2, placebo-controlled randomized trial reported that Peg-IFN $\lambda$-1 has potential to prevent clinical deterioration and shorten duration of viral shedding. Peg-IFN $\lambda-1$ accelerated viral decline in outpatients with COVID-19, increasing the proportion of patients with viral clearance by day 7 , particularly in those with high baseline viral load. ${ }^{26}$ However, it should be mentioned that IFN- $\lambda$ has been shown to increase susceptibility to pneumonia caused by methicillin-resistant staphylococcus aureus in response to influenza virus infection in mice. ${ }^{27}$ Broggi et al also found that IFN- $\lambda$ induced barrier damage of airway epithelium in mice. ${ }^{28}$ The amounts of IFN- $\lambda$ mRNA in bronchoalveolar lavage fluid and naso-oropharyngeal samples were correlated with the morbidity of SARS-CoV-2positive patients. Thus, it is cautious to use the IFN- $\lambda$.

Being different with IFN I and IFN III, IFN II (IFN- $\gamma$ ) is an independent risk factor associated with mortality in patients with moderate and severe COVID-19, as the higher level of IFN- $\gamma$ was found in the death than the that of survivals (median of $323 \mathrm{pg} / \mathrm{mL}$ vs $208 \mathrm{pg} / \mathrm{mL}$, $\mathrm{p}=0.017){ }^{29}$

\section{Thymosin}

Thymosin, a small molecular peptide with physiological activity is extracted from thymus of animals and human. ${ }^{30}$ Thymosin alpha 1 is produced as synthetic peptide and the most used form as drug. Thymosin preparations play a major role in maintaining the immune response of patients with primary immunodeficiency, autoimmune diseases and cancer, by stimulating the activity of specific lymphocytes. ${ }^{31}$ Acting as an immune potentiator, thymosin promotes the differentiation and maturation of thymocytes, increases the number and activity of $\mathrm{T}$ cells. ${ }^{32}$ Thymosin produce various cytokines such as IFN- $\gamma$, IL-2 and IL-3 through Th1, and increase the expression of IL-2 receptor through the activation of mitogen or antigen. ${ }^{33}$ It can also promote the recruitment of precursor NK cells, and the differentiation and function enhancement of bone marrowderived dendritic cells (DC). ${ }^{34}$ Activated macrophages or DC secrete IL-12, which strongly induces the differentiation of CD4+ $\mathrm{T}$ cells into Th1 cells. Th1 response is accompanied by a significant antiviral response, while Th2 response is accompanied by the continuation of viral 
infection and immune escape. In addition, because of its ability to increase the production of macrophage migration inhibitory factor and IFN- $\gamma$, it has been widely used for antiviral treatment of hepatitis B and HIV. ${ }^{32}$

As for the COVID-19, thymosin might restrict the progression of COVID-19 by stimulating the production and activity of lymphocytes, especially for the patients with lymphopenia. A multicenter retrospective cohort study (334 cases of COVID-19 enrolled) showed that the administration of thymosin- $\alpha(1.6 \mathrm{mg}$ qd or $\mathrm{q} 12 \mathrm{~h}$ for $>5$ days) significantly reduced the 28-day mortality (HR, 0.11 , $\mathrm{P}=0.013$ ) of the critical patients with lymphocyte $<0.73 \times$ $10^{9} / \mathrm{L}, \mathrm{PaO}_{2} / \mathrm{FiO}_{2}<196$, SOFA $>3$, and acute physiology and chronic health evaluation (APACHE) II $>7 .{ }^{35}$ Gender differences may be a factor in sustaining COVID-19 immunity responded to thymosin $\alpha 1$. It was found that the levels of CRP and IL- 6 were higher in Ta1-treated male than Ta1-treated female, while the level of PCT was significantly lower in T $\alpha 1$-treated male group. ${ }^{36}$ Another study demonstrated that $\mathrm{T} \alpha 1$ mitigates peripheral blood cytokine expression and inhibits lymphocyte activation specifically in a $\mathrm{CD} 8^{+}$T-cell subset from patients with COVID-19 in vitro, suggesting the potential to modulate immune response homeostasis and the cytokine storm in vivo. ${ }^{37}$ However, another multicenter retrospective study (771 cases) did not find the association between the use of thymosin- $\alpha 1$ and the decreased mortality in critically ill COVID-19 patients. ${ }^{38}$ The inconsistence may attribute to the difference of study subjects, severity of the COVID19 , proportion of the genders, and the dose and timepoint of administration, etc. Nevertheless, the use of thymosin$\alpha 1$ is still controversial.

\section{Glucocorticoids (GCs)}

Glucocorticoids (GCs) potently suppress the levels of proinflammatory cytokines. ${ }^{39} \mathrm{GCs}$ can inhibit the phospholipase A2, affect a cascading group of reactions of arachidonic acid, stabilize the lysosomal membrane and reduce tissue and cell damage. GCs suppress the binding of NF-KB to GCs response elements on DNA directly, reducing the expression of cytokines like IL- 6 , TNF- $\alpha$, and IL-1 $\beta$, etc. It can also activate the inhibitory nuclear factor $\mathrm{I} \kappa \mathrm{B} \alpha$, initiating the transcription of anti-inflammatory factor IL-10. ${ }^{40}$ GCs reduce the permeability of capillaries and improve the sensitivity of blood vessels to catecholamines to constrict blood vessels and reduce inflammation, ${ }^{41}$ inhibit the inflammation process of ARDS. ${ }^{42}$ Medium-to-low-dose glucocorticoids (Methylprednisolone $20-40 \mathrm{mg} / \mathrm{d}$, less than 8 days) plays a protective role in the respiratory and digestive systems by activating ACE2 and decreasing the level and IL-6 in 9 severe to critical patients with COVID- $19 .{ }^{43}$ A recent randomized clinical trial showed that the dexamethasone reduced 28-day mortality among the patients with COVID-19, who were treated by invasive mechanical ventilation (IMV) or oxygen at randomization. ${ }^{44}$ In this study, 2104 patients received dexamethasone (6 $\mathrm{mg}$, once daily, oral or intravenous for up to 10 days) reduced deaths by one-third in patients receiving IMV (29.0\% vs $40.7 \%)$, by one-fifth in patients receiving oxygen without IMV (21.5\% vs $25.0 \%)$, but did not reduce the mortality of patients without respiratory support at randomization $(17.0 \%$ vs. $13.2 \%, p=0.14)$, compared with 4321 patients concurrently allocated to usual care. Another study retrospectively compared the effectiveness of methylprednisolone to dexamethasone in patients with COVID-19 requiring intensive care in urban Los Angeles. In this study, all-cause mortalities in the usual care, methylprednisolone, and dexamethasone groups were $41.3 \%, 16.4 \%$ and $26.5 \%$ at 50 days $(P<0.01)$ respectively. ${ }^{45}$ It was found that in patients requiring mechanical ventilation, mortality was $42 \%$ lower in the methylprednisolone group than in the dexamethasone group (hazard ratio $0.48,95 \% \mathrm{CI}: 0.235-0.956, \mathrm{P}=0.0385$ ).

However, the immunosuppressed effect of GCs should be considered, for the risk of delaying virus clearance and increasing the secondary infection. Thus, the optimal GCs administration juncture timepoint, dosage, and duration might be subjected to further exploration to prevent the progression of ARDS. GCs used in the early stage of the disease did not show significant efficacy, but several studies have confirmed the efficacy of GCs in severe patients. ${ }^{16}$ The useness of GCs is recommended when the following clinical indicators occur, increased resting respiratory rate $(>30$ breaths/minute), ongoing deterioration in oxygenation index, multi-lobular progression ( $>50 \%)$ on imaging within $48 \mathrm{~h}$, consistent lymphopenia, etc. ${ }^{46,47}$

\section{IL-6 Receptor Antagonist}

Tocilizumab (TCZ), a humanized IgG1k monoclonal antibody, binds soluble or membrane-type IL-6 receptors (sIL6R and mIL-6R) specifically, and inhibit the signal transduction mediated by sIL-6R and mIL-6R. In the process of inflammation response, IL-6 regulates innate immunity via interacting with innate immune cells directly or indirectly activating stromal cells on inflammatory sites. ${ }^{48}$ These actions affect the recruitment, functional activation and differentiation of leukocytes, as well as the development of cytokine storm. ${ }^{49}$ 
TCZ has been widely used in the treatment of autoimmune diseases such as rheumatoid. It was found to reduce the 28-day mortality of patients with sepsis (IL-6 > $1000 \mathrm{pg} / \mathrm{mL}$ ). ${ }^{50}$

Excessive inflammation response can trigger cytokine storms and cause damage to multiple target organs in COVID-19. ${ }^{12}$ IL-6 played a major role in the development of cytokine storm and indicated the poor outcome of severe patients with COVID-19. TCZ was recommended to the patients of COVID-19 with elevated IL-6 levels to suppress the cytokine storm. ${ }^{10}$ A case report showed that in a 42-year -old male suffering from respiratory failure due to SARSCoV-2 infection, after 4 days of TCZ treatment, the CRP decreased from 225 to $33 \mathrm{mg} / \mathrm{L}$ and ultimately clinically fully recovered. ${ }^{51}$ A retrospective study analyzing 15 cases of COVID-19 by Luo et al found that TCZ deceased the plasma level of CRP and IL-6 in 10 patients. ${ }^{52}$ A single center study of 100 COVID-19 patients with hyperinflammatory syndrome and ARDS demonstrates that ten-day treatment with TCZ increases lymphocyte count, decrease the levels of CRP, fibrinogen, ferritin and IL-6. The study also showed that the respiratory condition was improved or stabilized in 77 (77\%) patients. ${ }^{53}$ An analysis of 90-day survival showed improved survival in the pooled interleukin-6 receptor antagonist groups, yielding a hazard ratio for the comparison with the control group of 1.61 (95\% credible interval, 1.25 to 2.08 ) and a posterior probability of superiority of more than $99.9 \%$ for the critically Ill Patients. $^{54}$ A multicenter, single-arm, hypothesis-driven trial found that TCZ reduced lethality rate at 14 and 30 days $(18.4 \%$ vs $20 \%, \mathrm{P}=0.52$; and $22.4 \%$ vs $35 \%, \mathrm{P}<$ $0.001) .{ }^{55}$ Therefore, the efficacy of TCZ could be expected in severe and critical patients. However, a cautionary case report by Radbel et al demonstrated that two patients with COVID-19 complicated by cytokines release syndrome (CRS) and treated with TCZ, but unfortunately, both patients progressed to severe hemophagocytic histiocytosis (HLH), and one developed to viral myocarditis. ${ }^{56}$ The hazard ratio for intubation or death in the tocilizumab group as compared with the placebo group was $0.83(95 \%$ confidence interval $[\mathrm{CI}], 0.38$ to $1.81 ; \mathrm{P}=0.64)$, and the hazard ratio for disease worsening was 1.11 (95\% CI, 0.59 to $2.10 ; \mathrm{P}=0.73) .{ }^{57}$ In addition, a randomized, open label trial in Brazil found TCZ plus standard care was not superior to standard care alone in improving clinical outcomes at 15 days, and it might increase mortality in patients with severe or critical COVID-19. ${ }^{58}$ Furthermore, a metaanalysis showed that the TCZ did not reduce short-term mortality. ${ }^{59}$ The effect of single anticytokine approach such as IL-6 receptor antagonist may be limited, possibly because it cannot overcome the complicated inflammatory response in COVID-19.

\section{IL-I Receptor Antagonist}

IL- $1 \beta$ is also a pro-inflammatory cytokine involved in the inflammatory response to COVID-19, which mediates immune responses and maintains the acute and chronic inflammatory. Early blockade of the IL-1 receptor is therapeutic in acute hyperinflammatory respiratory failure in COVID-19 patients.

Anakinra is an IL-1 receptor antagonist that blocks the activity of IL- $1 \alpha$ and IL-1 $\beta$. Recently, a multicenter, openlabel, Bayesian randomized clinical trial reported that 21 $(36 \%)$ of 59 patients in the anakinra group had a WHO-CPS score of more than 5 at day 4 versus $21(38 \%)$ of 55 in the usual care group. At day 14, 28 (47\%; 95\% CI 33 to 59) patients in the anakinra group and 28 (51\%; 95\% CI 36 to 62 ) in the usual care group needed ventilation or died. ${ }^{60}$ These data suggested anakinra did not improve outcomes in patients with mild-to-moderate COVID-19. A cohort study was conducted in Italy to compare the inhibitory effects of IL-1 and IL-6 in patients with COVID-19, respiratory insufficiency, and hyperinflammation. In the multivariable analysis, compared with patients who did not receive IL inhibitors, patients treated with IL-1 inhibition had a significantly reduced mortality risk (hazard ratio [HR] $0.450,95 \%$ CI $0.204-0.990, \mathrm{p}=0.047) .{ }^{61}$ A retrospective study found that all of the patients treated with anakinra improved clinically ( $\mathrm{P}<0.01)$, with no deaths, significant decreases in oxygen requirements $(\mathrm{P}<0.05)$, and more days without invasive mechanical ventilation $(\mathrm{P}<0.06) .{ }^{62}$ After 21 days treatment with high-dose intravenous anakinra, 21 (72\%) of 29 patients with COVID-19, ARDS and hyperinflammation showed reductions in serum $\mathrm{C}$-reactive protein and progressive improvements in respiratory function. ${ }^{63}$ Thomas et al observed a significant reduction of mortality, along with a significant decrease in the need of mechanical invasive ventilation with no obvious adverse events in severe forms of COVID-19 patients treated with anakinra. ${ }^{64}$ These data suggested that administration of anakinra in patients with an exacerbating form of COVID19 resulting from cytokine storm has a positive effect.

Canakinumab is a fully human IgG monoclonal antibody that specifically targets IL-1 $\beta$. In the US and EU, it is approved for a variety of autoinflammatory syndromes. ${ }^{65}$ An observational, cohort, prospective study showed that patients hospitalized treated with canakinumab, oxygen- 
support requirements improved and overall mortality decreased to $13.6 \%{ }^{65}$ A prospective case-control study showed that patients treated with canakinumab experienced a significant increase in $\mathrm{PaO} 2$ :FiO2 $(\mathrm{p}<0.001)$ and reduction in lung damage by CT $(p=0.01)$, along with significant decreases in immune/inflammation markers. Thus, canakinumab reduces the need for invasive mechanical ventilation and improve clinical symptoms in patients with moderate COVID-19. ${ }^{66}$

\section{Intravenous $\gamma$-Immunoglobulin (IVIG)}

The commercial intravenous $\gamma$-immunoglobulin (IVIG) is a plasma product extracted from a large amount of healthy human blood. It usually contains main IgG, with little $\operatorname{IgA}$ and IgM. IVIG exerts a non-specific antiviral effect and been used as an adjunctive treatment of severe pneumonia related to influenza. ${ }^{67}$ In critically ill patients with COVID-19, the innate immunity is insufficient to limit the virus, and the adaptive immune does not establish usually until 10 days after the onset. Thus, injection of IVIG helps to eliminate the virus partially. Xie et al investigated 58 cases of severe to critical COVID-19 with lymphocyte less than $0.5 \times 10^{9} / \mathrm{L}$, who received IVIG at $20 \mathrm{~g} /$ day. $^{68}$ The results showed that IVIG injection within $48 \mathrm{~h}$ of admission reduced the proportion of patients requiring mechanical ventilation $(6.67 \%$ vs $32.14 \%, p=0.016)$, length of stay in the hospital $(11.50 \pm$ 1.030 vs. $16.96 \pm 1.620$ days, $p=0.0055)$ and ICU stay $(11.50$ \pm 1.030 vs $16.96 \pm 1.620$ days, $p=0.0055)$, and ultimately decrease the 28 -day mortality $(23.3 \%$ vs $57.1 \%, p=0.009)$, comparing with the control. Recently, an observational research investigated the therapeutic effects of infliximab, IVIG, or combination therapy in patients with severe COVID-19 disease admitted to the ICU. According to the findings of this study, the expired rate was $37 \%$ in the infliximab group, $26.1 \%$ in IVIg, $45.5 \%$ in combination therapy, and $62.8 \%$ in the control group, respectively (all $\mathrm{P}<0.05)$. Hazard ratios of death were 0.31 in IVIG $(95 \%$ CI: $0.12-0.76, \mathrm{P}=0.01), 0.30$ in infliximab (95\% CI: 0.13 $0.67, \mathrm{P}=0.004), 0.39$ in combination therapy ( $95 \% \mathrm{CI}: 0.12$ $1.09, \mathrm{P}=0.071) .{ }^{69}$ It seems that infliximab and IVIG, alone or together, in patients with severe COVID-19 disease can be considered an effective treatment. An open-label, multicenter, comparative, randomized study found that duration of hospital stay was significantly shorter in IVIG group than that of standard care alone (7.7 vs. 17.5 days). ${ }^{70}$ Duration for normalization of body temperature, oxygen saturation and mechanical ventilation were significantly shorter in IVIG compared to standard care. However, a retrospective study for non-severe patients with COVID-19 reported that no statistically significant differences were found between IVIG group and control group in the duration of fever (median, 3 vs 3 days, $p=0.667$ ), virus clearance time (median, 11 vs.10 days, $\mathrm{p}=0.288$ ), length of hospital stay (median, $14 \mathrm{vs}$ 13 days, $p=0.469)$, and the use of antibiotics ( $40 \%$ vs $38.9 \%$, $\mathrm{p}=0.901) .^{71}$ Thus, IVIG can be considered for use in severe and critically ill patients, although it may not be suitable for non-severe ones. In summary, IVIG acts as a safe and efficacious combination therapy with other antiviral drugs for severe patients with COVID-19.

\section{Convalescent Plasma and Monoclonal Antibody of SARS-CoV-2}

The convalescent plasma, containing number of neutralizing antibodies, reduces the mortality of the severe patients with influenza A, MERS-CoV, and SARS-CoV. ${ }^{18}$ The immunotherapeutic potential of convalescent plasma for COVID-19 is also reasonable for the comparable virology and pathology with SARS and MERS. ${ }^{40,72}$ It has been shown that the improvement in 5 critically ill patients with COVID-19 who received $400 \mathrm{~mL}$ of convalescent plasma. After the plasma transfusion, the body temperature normalized within 3 days in 4 of 5 patients, $\mathrm{PaO}_{2}$ $/ \mathrm{FiO}_{2}$ increased (from 172-276 pre- to 284-366 posttreatment) within 12 days. 3 patients were weaned from mechanical ventilation within 2 weeks of treatment. ${ }^{73}$ Duan et al reported that $200 \mathrm{~mL}$ of convalescent plasma brought improvement of oxygen saturation (median: 93\% vs $96 \%)$, lymphopenia $\left(0.65 \times 10^{9} / \mathrm{L}\right.$ vs $\left.0.76 \times 10^{9} / \mathrm{L}\right)$, C-reactive protein $(55.98 \mathrm{mg} / \mathrm{L}$ vs $18.13 \mathrm{mg} / \mathrm{L})$, and CT scan in 10 patients with severe COVID-19. ${ }^{74}$

Monoclonal antibodies (mAbs) are produced by B cells under the stimulation of specific target antigens. ${ }^{75}$ Most of the antiviral mAbs studied so far are IgG. The viruses or infected cells combine with IgG to form antigen antibody complexes, which bind the $\mathrm{FC} \gamma$ receptors on the surface of killer cells (NK cells, macrophages, etc.). The virus is eliminated by antibody dependent cell-mediated cytotoxicity (ADCC). ${ }^{76}$ Thus, the monoclonal antibodies for the SARS-CoV-2 are effective in elimination of virus. As the relatively high identity of receptor-binding domain (RBD) in SARS-CoV-2 and SARS-CoV, Tian and Yuan found that the SARS-CoV-specific human monoclonal antibody, CR3022, could bind potently with SARS-CoV-2 RBD in vitro. $^{77,78}$ However, potent SARS-CoV-specific neutralizing antibodies of m396 and CR3014 that target the ACE2 
binding site failed to bind SARS-CoV-2 spike protein. ${ }^{77}$ Due to its relatively fast approval route and generally favorable safety profiles, mAb therapy should be a promising alternative to the treatment and prevention of emerging viral threats. ${ }^{79}$

\section{Limitations}

Although several agents rounding up the immunopathology of COVID-19 have been used clinically, and showed benefits for the patients, such as IFNs, thymosin, glucocorticoids, and IVIG, etc. It is worth mentioning that some drugs which are already granted by Emergency Use Authorization (EUA) have not been involved in our review, including monoclonal antibodies such as Bamlanivimab, Casirivimab, and Imdevimab. ${ }^{80}$

\section{Conclusions}

In summary, immune dysregulation, dysfunction and immunopathological injury are crucial to the elimination of virus and the progression of COVID-19. The agents to restore the unbalance of the immune response could be the alternative treatment approach under the scenario of the lacking of effective antiviral drugs.

\section{Funding}

This work was supported by the National Nature Science Foundation of China (81770084 and 82070089), the Key Research Program of Shanghai Science and Technology Commission (grant number 18140903600), the National Key Technology Research and Development Program of China (2018YFC1311900), and Shanghai Key Laboratory of Emergency Prevention, Diagnosis and Treatment of Respiratory Infectious Diseases (20dz2261100).

\section{Disclosure}

The authors declare no conflicts of interest and do not receive any funding source related to their professional activity that could influence the preparation of the manuscript.

\section{References}

1. Siddiqi HK, Mehra MR. COVID-19 illness in native and immunosuppressed states: a clinical-therapeutic staging proposal. J Heart Lung Transplant. 2020;39(5):405-407. doi:10.1016/j.healun.2020.03.012

2. Li G, Fan Y, Lai Y, et al. Coronavirus infections and immune responses. J Med Virol. 2020;92(4):424-432. doi:10.1002/jmv.25685

3. Lukassen S, Chua RL, Trefzer T, et al. SARS-CoV-2 receptor ACE2 and TMPRSS2 are primarily expressed in bronchial transient secretory cells. EMBO J. 2020;39(10):e105114. doi:10.15252/embj.2020105114
4. Xu Z, Shi L, Wang Y, et al. Pathological findings of COVID-19 associated with acute respiratory distress syndrome. Lancet Respir Med. 2020;8(4):420-422. doi:10.1016/S2213-2600(20)30076-X

5. Qin C, Zhou L, Hu Z, et al. Dysregulation of immune response in patients with Coronavirus 2019 (COVID-19) in Wuhan, China. Clin Infect Dis. 2020;71(15):762-768. doi:10.1093/cid/ciaa248

6. Wan S, Yi Q, Fan S, et al. Relationships among lymphocyte subsets, cytokines, and the pulmonary inflammation index in coronavirus (COVID-19) infected patients. $B r \quad J$ Haematol. 2020;189 (3):428-437. doi:10.1111/bjh.16659

7. Zeng Q, Li Y-Z, Huang G, Wu W, Dong S-Y, Xu Y. Mortality of COVID-19 is associated with cellular immune function compared to immune function in Chinese Han Population. medRxiv. 2020;2020.

8. Chan JF, Yuan S, Kok KH, et al. A familial cluster of pneumonia associated with the 2019 novel coronavirus indicating person-toperson transmission: a study of a family cluster. Lancet. 2020;395 (10223):514-523. doi:10.1016/S0140-6736(20)30154-9

9. Liu J, Li S, Liu J, et al. Longitudinal characteristics of lymphocyte responses and cytokine profiles in the peripheral blood of SARS-CoV-2 infected patients. EBioMedicine. 2020;55:102763. doi:10.1016/j.ebiom.2020.102763

10. Zhou F, Yu T, Du R, et al. Clinical course and risk factors for mortality of adult inpatients with COVID-19 in Wuhan, China: a retrospective cohort study. Lancet. 2020;395(10229):1054-1062. doi:10.1016/S0140-6736(20)30566-3

11. Sharma D, Jakkampudi A, Reddy R, et al. Association of systemic inflammatory and anti-inflammatory responses with adverse outcomes in acute pancreatitis: Preliminary Results of an Ongoing Study. Dig Dis Sci. 2017;62(12):3468-3478. doi:10.1007/s10620017-4813-6

12. Huang C, Wang Y, Li X, et al. Clinical features of patients infected with 2019 novel coronavirus in Wuhan, China. Lancet. 2020;395 (10223):497-506. doi:10.1016/S0140-6736(20)30183-5

13. Mathew D, Giles JR, Baxter AE, et al. Deep immune profiling of COVID-19 patients reveals patient heterogeneity and distinct immunotypes with implications for therapeutic interventions. bioRxiv. 2020.

14. Ragab D, Salah Eldin H, Taeimah M, Khattab R, Salem R. The COVID-19 cytokine storm; what we know so far. Front Immunol. 2020;11:1446. doi:10.3389/fimmu.2020.01446

15. Lai CC, Shih TP, Ko WC, Tang HJ, Hsueh PR. Severe acute respiratory syndrome coronavirus 2 (SARS-CoV-2) and coronavirus disease-2019 (COVID-19): the epidemic and the challenges. Int $J$ Antimicrob Agents. 2020;55(3):105924. doi:10.1016/j. ijantimicag.2020.105924

16. Rizk JG, Kalantar-Zadeh K, Mehra MR, Lavie CJ, Rizk Y, Forthal DN. Pharmaco-immunomodulatory therapy in COVID-19. Drugs. 2020;80(13):1267-1292. doi:10.1007/s40265-020-01367-z

17. Cao W, Liu X, Bai T, et al. High-dose intravenous immunoglobulin as a therapeutic option for deteriorating patients with coronavirus disease 2019. Open Forum Infect Dis. 2020;7(3):ofaa102. doi:10.1093/ofid/ofaa102

18. Mair-Jenkins J, Saavedra-Campos M, Baillie JK, et al. The effectiveness of convalescent plasma and hyperimmune immunoglobulin for the treatment of severe acute respiratory infections of viral etiology: a systematic review and exploratory meta-analysis. $J$ Infect Dis. 2015;211(1):80-90. doi:10.1093/infdis/jiu396

19. Gibbert K, Schlaak JF, Yang D, Dittmer U. IFN-alpha subtypes: distinct biological activities in anti-viral therapy. $\mathrm{Br} J$ Pharmacol. 2013;168(5):1048-1058. doi:10.1111/bph.12010

20. McNab F, Mayer-Barber K, Sher A, Wack A, O'Garra A. Type I interferons in infectious disease. Nat Rev Immunol. 2015;15 (2):87-103.

21. Hadjadj J, Yatim N, Barnabei L, et al. Impaired type I interferon activity and inflammatory responses in severe COVID-19 patients. Science. 2020;369(6504):718-724. doi:10.1126/science.abc6027 
22. Sallard E, Lescure FX, Yazdanpanah Y, Mentre F, Peiffer-Smadja N. Type 1 interferons as a potential treatment against COVID-19. Antiviral Res. 2020;178:104791. doi:10.1016/j.antiviral.2020.104791

23. Zhou Q, Chen V, Shannon CP, et al. Interferon-alpha2b treatment for COVID-19. Front Immunol. 2020;11:1061. doi:10.3389/ fimmu.2020.01061

24. Hung IF, Lung KC, Tso EY, et al. Triple combination of interferon beta-1b, lopinavir-ritonavir, and ribavirin in the treatment of patients admitted to hospital with COVID-19: an open-label, randomised, phase 2 trial. Lancet. 2020;395(10238):1695-1704. doi:10.1016/ S0140-6736(20)31042-4

25. Consortium WHOST, Pan H, Peto R, et al. Repurposed antiviral drugs for covid-19 - interim WHO solidarity trial results. $N$ Engl $J$ Med. 2021;384(6):497-511.

26. Feld JJ, Kandel C, Biondi MJ, et al. Peginterferon lambda for the treatment of outpatients with COVID-19: a phase 2, placebo-controlled randomised trial. Lancet Respir Med. 2021;9 (5):498-510. doi:10.1016/S2213-2600(20)30566-X

27. Planet PJ, Parker D, Cohen TS, et al. Lambda interferon restructures the nasal microbiome and increases susceptibility to Staphylococcus aureus superinfection. mBio. 2016;7(1):e01939-e01915. doi:10.1128/ mBio.01939-15

28. Broggi A, Ghosh S, Sposito B, et al. Type III interferons disrupt the lung epithelial barrier upon viral recognition. Science. 2020;369 (6504):706-712. doi:10.1126/science.abc3545

29. Gadotti AC, de Castro Deus M, Telles JP, et al. IFN-gamma is an independent risk factor associated with mortality in patients with moderate and severe COVID-19 infection. Virus Res. 2020;289:198171. doi:10.1016/j.virusres.2020.198171

30. King R, Tuthill C. Immune modulation with thymosin alpha 1 treatment. Vitam Horm. 2016;102:151-178.

31. Costantini C, Bellet MM, Pariano M, et al. A reappraisal of thymosin alpha1 in cancer therapy. Front Oncol. 2019;9:873. doi:10.3389/ fonc. 2019.00873

32. Matteucci C, Grelli S, Balestrieri E, et al. Thymosin alpha 1 and HIV-1: recent advances and future perspectives. Future Microbiol. 2017;12:141-155. doi:10.2217/fmb-2016-0125

33. Chandratilleke D, Marsh JA. The effect of thymulin on avian IL-2 receptor expression. Int J Immunopharmacol. 2000;22(11):887-896. doi:10.1016/S0192-0561(00)00051-5

34. Romani L, Bistoni F, Gaziano R, et al. Thymosin alpha 1 activates dendritic cells for antifungal Th1 resistance through toll-like receptor signaling. Blood. 2004;103(11):4232-4239. doi:10.1182/blood-2003$11-4036$

35. Wu M, Ji JJ, Zhong L, et al. Thymosin alphal therapy in critically ill patients with COVID-19: a multicenter retrospective cohort study Int Immunopharmacol. 2020;88:106873. doi:10.1016/j.intimp.2020. 106873

36. Li X, Liu L, Yang Y, et al. Gender-associated difference following COVID-19 virus infection: implications for thymosin alpha-1 therapy. Int Immunopharmacol. 2021;90:107022. doi:10.1016/j. intimp.2020.107022

37. Matteucci C, Minutolo A, Balestrieri E, et al. Thymosin alpha 1 mitigates cytokine storm in blood cells from coronavirus disease 2019 patients. Open Forum Infect Dis. 2021;8(1):ofaa588. doi:10.1093/ofid/ofaa588

38. Sun Q, Xie J, Zheng R, et al. The effect of thymosin alpha1 on mortality of critical COVID-19 patients: a multicenter retrospective study. Int Immunopharmacol. 2021;90:107143. doi:10.1016/j. intimp.2020.107143

39. Talaber G, Jondal M, Okret S. Extra-adrenal glucocorticoid synthesis: immune regulation and aspects on local organ homeostasis. Mol Cell Endocrinol. 2013;380(1-2):89-98. doi:10.1016/j.mce.2013.05.007
40. Meduri GU, Tolley EA, Chrousos GP, Stentz F. Prolonged methylprednisolone treatment suppresses systemic inflammation in patients with unresolving acute respiratory distress syndrome: evidence for inadequate endogenous glucocorticoid secretion and inflammation-induced immune cell resistance to glucocorticoids. Am $J$ Respir Crit Care Med. 2002;165(7):983-991. doi:10.1164/ ajrccm.165.7.2106014

41. Cain DW, Cidlowski JA. Immune regulation by glucocorticoids. Nat Rev Immunol. 2017;17(4):233-247. doi:10.1038/nri.2017.1

42. Meduri GU, Annane D, Chrousos GP, Marik PE, Sinclair SE. Activation and regulation of systemic inflammation in ARDS: rationale for prolonged glucocorticoid therapy. Chest. 2009;136 (6):1631-1643. doi:10.1378/chest.08-2408

43. Xiang Z, Liu J, Shi D, et al. Glucocorticoids improve severe or critical COVID-19 by activating ACE2 and reducing IL-6 levels. Int J Biol Sci. 2020;16(13):2382-2391. doi:10.7150/ijbs.47652

44. Group RC, Horby P, Lim WS, et al. Dexamethasone in hospitalized patients with covid-19 - preliminary report. $N$ Engl J Med. 2020.

45. Ko JJ, Wu C, Mehta N, Wald-Dickler N, Yang W, Qiao R. A comparison of methylprednisolone and dexamethasone in intensive care patients with COVID-19. J Intensive Care Med. 2021;36 (6):885066621994057. doi:10.1177/0885066621994057

46. Zhou M, Zhang X, Qu J. Coronavirus disease 2019 (COVID-19): a clinical update. Front Med. 2020;14(2):126-135. doi:10.1007/ s11684-020-0767-8

47. $\mathrm{Xu} \mathrm{XW}, \mathrm{Wu} \mathrm{XX}$, Jiang $\mathrm{XG}$, et al. Clinical findings in a group of patients infected with the 2019 novel coronavirus (SARS-Cov-2) outside of Wuhan, China: retrospective case series. BMJ. 2020;368: m606. doi:10.1136/bmj.m606

48. Hunter CA, Jones SA. IL-6 as a keystone cytokine in health and disease. Nat Immunol. 2015;16(5):448-457. doi:10.1038/ni.3153

49. Jones SA, Jenkins BJ. Recent insights into targeting the IL-6 cytokine family in inflammatory diseases and cancer. Nat Rev Immunol. 2018;18(12):773-789.

50. Panacek EA, Marshall JC, Albertson TE, et al. Efficacy and safety of the monoclonal anti-tumor necrosis factor antibody $\mathrm{F}\left(\mathrm{ab}^{\prime}\right) 2$ fragment afelimomab in patients with severe sepsis and elevated interleukin-6 levels. Crit Care Med. 2004;32(11):2173-2182. doi:10.1097/01. CCM.0000145229.59014.6C

51. Michot JM, Albiges L, Chaput N, et al. Tocilizumab, an anti-IL-6 receptor antibody, to treat COVID-19-related respiratory failure: a case report. Ann Oncol. 2020;31(7):961-964. doi:10.1016/j. annonc.2020.03.300

52. Luo P, Liu Y, Qiu L, Liu X, Liu D, Li J. Tocilizumab treatment in COVID-19: a single center experience. J Med Virol. 2020;92 (7):814-818. doi:10.1002/jmv.25801

53. Toniati P, Piva S, Cattalini M, et al. Tocilizumab for the treatment of severe COVID-19 pneumonia with hyperinflammatory syndrome and acute respiratory failure: a single center study of 100 patients in Brescia, Italy. Autoimmun Rev. 2020;19(7):102568. doi:10.1016/j. autrev.2020.102568

54. Investigators R-C, Gordon AC, Mouncey PR, et al. Interleukin-6 receptor antagonists in critically ill patients with covid-19. $N$ Engl J Med. 2021;384(16):1491-1502.

55. Perrone F, Piccirillo MC, Ascierto PA, et al. Tocilizumab for patients with COVID-19 pneumonia. The single-arm TOCIVID-19 prospective trial. $J$ Transl Med. 2020;18(1):405. doi:10.1186/s12967-02002573-9

56. Radbel J, Narayanan N, Bhatt PJ. Use of tocilizumab for COVID-19induced cytokine release syndrome: a cautionary case report. Chest. 2020;158(1):e15-e19. doi:10.1016/j.chest.2020.04.024

57. Stone JH, Frigault MJ, Serling-Boyd NJ, et al. Efficacy of tocilizumab in patients hospitalized with covid-19. $N$ Engl J Med. 2020;383 (24):2333-2344. doi:10.1056/NEJMoa2028836 
58. Veiga VC, Prats J, Farias DLC, et al. Effect of tocilizumab on clinical outcomes at 15 days in patients with severe or critical coronavirus disease 2019: randomised controlled trial. BMJ. 2021;372:n84. doi:10.1136/bmj.n84

59. Tleyjeh IM, Kashour Z, Damlaj M, et al. Efficacy and safety of tocilizumab in COVID-19 patients: a living systematic review and meta-analysis. Clin Microbiol Infect. 2021;27(2):215-227. doi:10.1016/j.cmi.2020.10.036

60. Group C-C. Effect of anakinra versus usual care in adults in hospital with COVID-19 and mild-to-moderate pneumonia (CORIMUNO-ANA-1): a randomised controlled trial. Lancet Respir Med. 2021.

61. Cavalli G, Larcher A, Tomelleri A, et al. Interleukin-1 and interleukin-6 inhibition compared with standard management in patients with COVID-19 and hyperinflammation: a cohort study. Lancet Rheumatol. 2021;3(4):e253-e261.

62. Cauchois R, Koubi M, Delarbre D, et al. Early IL-1 receptor blockade in severe inflammatory respiratory failure complicating COVID-19. Proc Natl Acad Sci U S A. 2020;117(32):18951-18953. doi:10.1073/pnas.2009017117

63. Cavalli G, De Luca G, Campochiaro C, et al. Interleukin-1 blockade with high-dose anakinra in patients with COVID-19, acute respiratory distress syndrome, and hyperinflammation: a retrospective cohort study. Lancet Rheumatol. 2020;2(6):e325-e331. doi:10.1016/ S2665-9913(20)30127-2

64. Huet T, Beaussier H, Voisin O, et al. Anakinra for severe forms of COVID-19: a cohort study. Lancet Rheumatol. 2020;2(7):e393-e400. doi:10.1016/S2665-9913(20)30164-8

65. Landi L, Ravaglia C, Russo E, et al. Blockage of interleukin-1beta with canakinumab in patients with covid-19. Sci Rep. 2020;10 (1):21775. doi:10.1038/s41598-020-78492-y

66. Generali D, Bosio G, Malberti F, et al. Canakinumab as treatment for COVID-19-related pneumonia: a prospective case-control study. Int $J$ Infect Dis. 2020;104:433-440. doi:10.1016/j.ijid.2020.12.073

67. Hung IFN, To KKW, Lee CK, et al. Hyperimmune IV immunoglobulin treatment: a multicenter double-blind randomized controlled trial for patients with severe 2009 influenza $\mathrm{A}(\mathrm{H} 1 \mathrm{~N} 1)$ infection. Chest. 2013;144(2):464-473. doi:10.1378/chest.12-2907

68. Xie Y, Cao S, Dong H, et al. Effect of regular intravenous immunoglobulin therapy on prognosis of severe pneumonia in patients with COVID-19. $J$ Infect. 2020;81(2):318-356. doi:10.1016/j. jinf.2020.03.044
69. Farrokhpour M, Rezaie N, Moradi N, et al. Infliximab and intravenous gammaglobulin in hospitalized severe COVID-19 patients in intensive care unit. Arch Iran Med. 2021;24(2):139-143. doi:10.34172/aim.2021.22

70. Raman RS, Barge VB, Anil kumar D, et al. A Phase II Safety and Efficacy Study on prognosis of moderate pneumonia in coronavirus disease 2019 patients with regular intravenous immunoglobulin therapy. J Infect Dis. 2021;223(9):1538-1543. doi:10.1093/infdis/ jiab098

71. Huang C, Fei L, Li W, et al. Efficacy evaluation of intravenous immunoglobulin in non-severe patients with COVID-19: a Retrospective Cohort Study based on propensity score matching. Int J Infect Dis. 2021;105:525-531. doi:10.1016/j.ijid.2021.01.009

72. Lee P-I, Hsueh P-R. Emerging threats from zoonotic coronaviruses-from SARS and MERS to 2019-nCoV. J Microbiol Immunol Infect. 2020;53(3):365-367. doi:10.1016/j.jmii.2020.02.001

73. Shen C, Wang Z, Zhao F, et al. Treatment of 5 critically ill patients with COVID-19 with convalescent plasma. JAMA. 2020;323 (16):1582-1589. doi:10.1001/jama.2020.4783

74. Duan K, Liu B, Li C, et al. Effectiveness of convalescent plasma therapy in severe COVID-19 patients. Proc Natl Acad Sci U S A. 2020;117(17):9490-9496. doi:10.1073/pnas.2004168117

75. Lu RM, Hwang YC, Liu IJ, et al. Development of therapeutic antibodies for the treatment of diseases. J Biomed Sci. 2020;27(1):1.

76. Jahanshahlu L, Rezaei N. Monoclonal antibody as a potential anti-COVID-19. Biomed Pharmacothe. 2020;129:110337. doi:10.1016/j.biopha.2020.110337

77. Tian X, Li C, Huang A, et al. Potent binding of 2019 novel coronavirus spike protein by a SARS coronavirus-specific human monoclonal antibody. Emerg Microbes Infect. 2020;9(1):382-385. doi:10.1080/22221751.2020.1729069

78. Yuan M, Wu NC, Zhu X, et al. A highly conserved cryptic epitope in the receptor binding domains of SARS-CoV-2 and SARS-CoV. Science. 2020;368(6491):630-633. doi:10.1126/science.abb7269

79. Walker LM, Burton DR. Passive immunotherapy of viral infections: 'super-antibodies' enter the fray. Nat Rev Immunol. 2018;18 (5):297-308. doi:10.1038/nri.2017.148

80. Rizk JG, Forthal DN, Kalantar-Zadeh K, et al. Expanded access programs, compassionate drug use, and emergency use authorizations during the COVID-19 pandemic. Drug Discov Today. 2021;26 (2):593-603. doi:10.1016/j.drudis.2020.11.025
Therapeutics and Clinical Risk Management

\section{Publish your work in this journal}

Therapeutics and Clinical Risk Management is an international, peerreviewed journal of clinical therapeutics and risk management, focusing on concise rapid reporting of clinical studies in all therapeutic areas, outcomes, safety, and programs for the effective, safe, and sustained use of medicines. This journal is indexed on PubMed Central, CAS,
EMBase, Scopus and the Elsevier Bibliographic databases. The manuscript management system is completely online and includes a very quick and fair peer-review system, which is all easy to use. Visit http://www.dovepress.com/testimonials.php to read real quotes from published authors. 